\title{
THE HERBAL MEDICINE CONTAINING OF IVY LEAF DRY EXTRACT IN THE TREATMENT OF PRODUCTIVE COUGH IN CHILDREN
}

DOI: $10.36740 /$ WLek202004108

\author{
Magdalena Olszanecka-Glinianowicz' ${ }^{1}$, Zbigniew Doniec ${ }^{2}$, Karina Schönknecht ${ }^{3}$, Agnieszka Almgren-Rachtan ${ }^{4}$ \\ 'HEALTH PROMOTION AND OBESITY MANAGEMENT UNIT, DEPARTMENT OF PATHOPHYSIOLOGY, MEDICAL FACULTY IN KATOWICE, MEDICAL \\ UNIVERSITY OF SILESIA IN KATOWICE, KATOWICE, POLAND \\ 2PNEUMONOLOGY CLINIC, INSTITUTE OF TUBERCULOSIS AND LUNG DISEASES, FIELD DEPARTMENT JAN AND IRENA RUDNIKOW, RABKA-ZDROJ, POLAND \\ ${ }^{3}$ MEDICAL AFFAIRS DEPARTMENT, PHYTOPHARM KLĘKA SA, POLAND \\ ${ }^{4}$ DEPARTAMENT OF PHARMACOVIGILANCE, EUROPHARMA M. RACHTAN LTD., KATOWICE, POLAND
}

\begin{abstract}
The aim: The assessment of the therapeutic effects of the herbal medicine containing of ivy leaf dry extract administered twice a day in children with productive cough and their guardians' satisfaction with the use of this syrup.

Material and methods: A multicenter, observational survey was conducted by 268 doctors working in Primary Health Care. The survey was conducted during two routine, consecutive outpatient visits (including first supplemented retrospectively) resulting from the needs of therapy.

Results: The study group consisted of 5162 patients treated for productive cough with the herbal medicine containing of ivy leaf dry extract administered twice a day. In $75.7 \%$, productive cough was intense, in $61.6 \%$ it occurred at night, in $49.8 \%$ it was very common (several times per hour), and in $62.7 \%$ it affected daily activity. Most often the syrup containing of ivy leaf dry extract was used in doses twice a day for $2 \mathrm{ml}$ or $4 \mathrm{ml}$. During observation the percentage of children with intensive, very common, night and affected daily activities cough decreased significantly. Very satisfied with a therapeutic effect of the preparation containing of ivy leaf dry extract administered twice a day were $68.2 \%$ of children guardians.

Conclusions: The use of the herbal medicine containing of ivy leaf dry extract administered twice a day may be a good alternative to current therapeutic regimens in the treatment of productive cough in children. This recommendation is supported by effectiveness comparable to other medicines and a high level of satisfaction with its use by patients and guardians of chidren.
\end{abstract}

KEY WORDS: productive cough, infection, ivy leaf extract, children, herbal medicine

\section{INTRODUCTION}

Cough is a reflex classified as a defense reaction in diseases of the respiratory system aimed at removing excess secretions, foreign bodies or irritants. The cough reflex may be caused by damage of the mucosa of the upper respiratory tract in the course of viral and bacterial infections or irritation of the nerves responsible for conduction of impulses of this reflex and a foreign body in the respiratory tract.

If the cough is accompanied by coughing up mucus or pus, it is considered as productive (wet) and if not as dry [1]. Since a productive cough allows the removal of accumulated secretions, it should not be inhibited, and even expectorants should be used, which will facilitate and accelerate the removal of secretions from the respiratory tract.

Substances used to treat productive cough are divided into: - expectorant drugs that increase the volume of secretions are: bromhexine, ambroxol, guaiacol compounds, saponins contained in the primrose, licorice, medical soap, ivy, and essential oils: eucalyptus, pine and anise, - mucolytic drugs that reduce the viscosity of secretions are: acetylcysteine, erdosteine, carbocysteine and mesne,
- mucokinetic drugs that increase the efficiency of ciliary transport (salbutamol) and reducing mucus adhesion to the epithelium (surfactant, ambroxol),

- mucoregulatory drugs are inhaled glucocorticosteroids and anticholinergics.

As already mentioned, expectorant drugs that increase the volume of secretions are plant preparations obtained from ivy leaves. This extract contains triterpene saponins (hederacoside $B$ and $C$ ), which give it secretolytic and antioxidant properties. They stimulate the cough reflex irritating the sensory nerve endings in the gastric mucosa, which by way of the vagus testicles significantly increases secretion in the respiratory tract. In addition, ivy leaf extract has a spasmolytic effect by reducing respiratory muscle tone, which means that it can be used for the symptomatic treatment of chronic bronchitis [2]. Treatment with preparations containing ivy leaf extract should last about 7 days. The use in children under 2 years of age is contraindicated because of thegeneral risk of aggravation of respiratory symptoms through secretolytic drugs. Carefully, these preparations should be used with caution in people with gastritis and gastric ulcer [3]. 
The study conducted in 50 children aged 2-10 years diagnosed with acute bronchitis, revealed that the efficacy of ivy leaf extract was comparable to acetylcysteine, and it was better tolerated [4].

The efficacy of ivy leaf extract has also been confirmed in clinical trials conducted among patients of different ages diagnosed with of chronic airway obstruction, chronic bronchitis, lung disease and acute respiratory bacterial infections [5-8].

One of the preparations containing of ivy leaf dry extract available on the Polish pharmaceutical market is syrup administered twice a day for 2 or $4 \mathrm{ml}$ in children aged 2-5 years and 6-12 years, respectively.

There are no Polish studies assessing the efficacy of this syrup in the treatment of productive cough in children in everyday medical practice and guardians' satisfaction with the use of this syrup.

\section{THE AIM}

Therefore, the aim of observational study was the assessment of therapeutic effects of the herbal medicine containing of ivy leaf dry extract administered twice a day in children with productive cough and guardians' satisfaction with the use of this syrup.

\section{MATERIAL AND METHODS}

A multi-center, observational survey was conducted by 268 pediatric and family medicine specialist and doctors implementing these specialization programs working in Primary Health Care from across the Polish. On average, each physician participating in the study included 20 patients meeting the inclusion criteria, such as age 2-12 years, productive cough treated with the herbal medicine containing of ivy leaf dry extract administered twice a day, and oral consent of guardian. The exclusion criteria were impossibility to obtain from the medical history and from the child's guardian full data necessary to complete the survey.

The study was a survey and did not require the consent of the Bioethical Committee. The survey was supplemented during two routine outpatient visits (the first supplemented retrospectively based on the patient's medical history after obtaining the consent of the patient's guardian to include the child treated with the herbal medicine Hedussin syrup (Phytopharm Klęka SA) containing of ivy leaf dry extract (Hedera helix L., folium) (4-8:1) - 8,25 mg / $1 \mathrm{ml}$, (extraction solvent: ethanol $30 \% \mathrm{~m} / \mathrm{m}$ ) administered twice a day in the study, resulting from the needs of therapy.

The part of the survey completed retrospectively contained socio-demographic data [gender, age and place of residence (city / village)] and clinical data (primary diagnosis due to the preparation containing of ivy leaf dry extract administered twice a day was used, severity of cough and the applied dose of study preparation). At visit 2, the severity of cough and satisfaction of the child's guardian with the use of the preparation containing of ivy leaf dry extract administered twice a day were assessed.

Statistical analysis was performed with Statistica 12.0 software (TIBCO Software Inc., Palo Alto, CA, USA). Values of variables were presented as percentages and the mean values with standard deviations (SD). Separate groups were compared using the $\mathrm{chi}^{2}$ test and $\mathrm{chi}^{2}$ test for trend. The value of $\mathrm{p}<0.05$ was considered to be statistically significant.

\section{RESULTS}

The study group consisted of 5,162 children treated for productive cough with the herbal medicine containing of ivy leaf dry extract administered twice a day. $47.8 \%$ of the study group were boys and $56.3 \%$ of children aged $2-5$ years. $72.9 \%$ of the surveyed children lived in cities. In $66.8 \%$ of respondents, productive cough was caused by viral infection of the upper respiratory tract, in $22.2 \%$ by bronchitis, and in $10.7 \%$ by bacterial infection of the upper respiratory infection. The characteristics of the study group are shown in Table 1.

In $75.7 \%$ of the examined group, productive cough was assessed as intense, in $61.6 \%$ it was at night, in $49.8 \%$ it was very common (several times an hour), and in $62.7 \%$ it affected daily activity. Most often, an intense cough occurred in children with bronchitis (94.5\%), and also most often occurred at night $(81.7 \%)$ and very often (several times per hour (73.9\%) and most often affected daily activity $(82.4 \%)$.

Most often the syrup containing of ivy leaf dry extract administered twice a day were applied at two times a day for 2 or $4 \mathrm{ml}$ (48.5\% and $41.7 \%$, respectively). In children with viral infections of the upper respiratory tract most often was used $2 \mathrm{ml}$ twice daily (53.6\%), in children with bacterial infections of the upper respiratory tract and bronchitis, $4 \mathrm{ml}$ twice daily was used most often $(48.1 \%$ and $49.1 \%$, respectively) - Table 3 .

At visit 2, which in $76.1 \%$ of respondents took place within 7 days of visit 1 and in $21.4 \%$ from 8 to 14 days after visit 1, wet cough persisted in $59.5 \%$ of the study group, most often in children diagnosed with bronchitis (79.4\%). In the all study group and in subgroups diagnosed with viral and bacterial infections of the upper respiratory tract and bronchitis, the percentage of children in whom the cough was assessed as intensive ( $p<0.001 ; p<0.001$; $\mathrm{p}<0.001$ and $\mathrm{p}<0.001$ ), with very common cough (several times per hour) ( $\mathrm{p}<0.001$; $\mathrm{p}<0.001$; $\mathrm{p}<0.001$ and $\mathrm{p}$ $<0.001$, respectively), with night cough ( $\mathrm{p}<0.001 ; \mathrm{p}<0.001$; $\mathrm{p}<0.001$ and $\mathrm{p}<0.001$, respectively) ) and with cough affected daily activities ( $\mathrm{p}<0.001$; $\mathrm{p}<0.001$; $\mathrm{p}<0.001$ and $\mathrm{p}$ $<0.001$, respectively) decreased significantly (Table 2 ). No adverse effects were reported during follow-up.

Very satisfied with the therapeutic effect of the herbal medicine containing of ivy leaf dry extract administered twice a day was $68.2 \%$ child guardians, with his regimen twice a day $79.5 \%$, with small volume which must be administered $80.8 \%$, and with its flavor $62.9 \%$. $96.7 \%$ of children guardians were willing to apply the product containing of this ivy leaf dry extract administered twice a day in case of recurrence of the productive cough in child. The most often dissatisfied with the therapeutic effect of the preparation containing of ivy leaf dry extract administered twice a day were guardians of children diagnosed with bronchitis $(6.7 \%$ vs. $4.2 \%$ and $3.3 \%$; p < $<0.01)$. They 
Table 1. Socio-demographic and clinical characteristics of the study group.

\begin{tabular}{|c|c|c|c|c|c|}
\hline & All study group & $\begin{array}{l}\text { Viral infection } \\
\text { of the upper } \\
\text { respiratory tract }\end{array}$ & $\begin{array}{l}\text { Bacterial infection of the } \\
\text { upper respiratory tract }\end{array}$ & Bronchitis & $\mathbf{p}$ \\
\hline & {$[\mathrm{N}=5.162]$} & {$[\mathrm{N}=3.448]$} & {$[\mathrm{N}=553]$} & {$[\mathrm{N}=1.146]$} & \\
\hline Boys [N; \%] & $2.467 ; 47.8$ & $1.617 ; 46.9$ & $274 ; 49.6$ & $572 ; 49.9$ & \multirow{2}{*}{ NS } \\
\hline Girls [N; \%] & $2.695 ; 52.2$ & $1.831 ; 53.1$ & $279 ; 50.4$ & $574 ; 50.1$ & \\
\hline Age [years] & $5.7 \pm 2.9$ & $5.4 \pm 2.8$ & $6.3 \pm 3.0$ & $6.2 \pm 3,0$ & 0.02 \\
\hline $2-5$ years $[\mathrm{N} ; \%]$ & $2.906 ; 56.3$ & $2.110 ; 61.2$ & $260 ; 47.0$ & $528 ; 46.0$ & \multirow{3}{*}{$<0.001$} \\
\hline $6-9$ years [N; \%] & $1.466 ; 28.4$ & $893 ; 25.9$ & $182 ; 32.9$ & $388 ; 33.9$ & \\
\hline $10-12$ years $[N ; \%]$ & $790 ; 15.3$ & $445 ; 12.9$ & $111 ; 20.0$ & $230 ; 20.1$ & \\
\hline \multicolumn{5}{|c|}{ Place of residence [N;\%] } & \\
\hline Urban & $3.763 ; 72.9$ & $2.576 ; 74.7$ & $370 ; 66.9$ & $804 ; 70.2$ & \multirow{2}{*}{$<0.001$} \\
\hline Rural & $1.399 ; 27.1$ & $872 ; 25.3$ & $183 ; 33.1$ & $342 ; 29.8$ & \\
\hline
\end{tabular}

The primary diagnosis [N;\%]

Bacterial infection of the upper respiratory tract

$553 ; 10.7$

Viral infection of the upper respiratory tract

$3.448 ; 66.8$

Bronhitis

$1.146 ; 22.2$

Other

$15 ; 0.3$

Dose of the study syrup used [N;\%]

\begin{tabular}{|c|c|c|c|c|c|}
\hline $2.0 \mathrm{ml}$ twice a day & $2.504 ; 48.5$ & $1.848 ; 53,6$ & $203 ; 36,7$ & $442 ; 38,6$ & $<0.001$ \\
\hline $4.0 \mathrm{ml}$ twice a day & $2.153 ; 41.7$ & $1.321 ; 38.3$ & $266 ; 48.1$ & $563 ; 49.1$ & $<0.001$ \\
\hline $6.0 \mathrm{ml}$ twice a day & $196 ; 3.8$ & $100 ; 2.9$ & $40 ; 7.3$ & $56 ; 4.9$ & $<0.001$ \\
\hline $5.0 \mathrm{ml}$ twice a day & $119 ; 2.3$ & $62 ; 1.8$ & $17 ; 3.0$ & $38 ; 3.3$ & 0.01 \\
\hline $3.0 \mathrm{ml}$ twice a day & $103 ; 2.0$ & $62 ; 1.8$ & $17 ; 3.0$ & $22 ; 1.9$ & NS \\
\hline $2.5 \mathrm{ml}$ twice a day & $26 ; 0.5$ & $14 ; 0.4$ & $3 ; 0.5$ & $8 ; 0.7$ & NS \\
\hline $3.5 \mathrm{ml}$ twice a day & $15 ; 0.3$ & $14 ; 0.4$ & $2 ; 0.4$ & 0 & NS \\
\hline $4.0 \mathrm{ml}$ three times a day & $10 ; 0.2$ & $7 ; 0.2$ & 0 & $6 ; 0.5$ & NS \\
\hline Other & $36 ; 0.7$ & $20 ; 0.6$ & $5 ; 0.9$ & $11 ; 1.0$ & NS \\
\hline
\end{tabular}

Table 2. Changes in the severity of productive cough during follow-up

\begin{tabular}{|c|c|c|c|c|c|c|c|c|c|c|c|c|}
\hline & \multicolumn{3}{|c|}{ All study group } & \multicolumn{3}{|c|}{$\begin{array}{l}\text { Viral infection of the } \\
\text { upper respiratory tract }\end{array}$} & \multicolumn{3}{|c|}{$\begin{array}{l}\text { Bacterial infection of the } \\
\text { upper respiratory tract }\end{array}$} & \multicolumn{3}{|c|}{ Bronchitis } \\
\hline & \multicolumn{3}{|c|}{$[\mathrm{N}=5.162]$} & \multicolumn{3}{|c|}{$[\mathrm{N}=3.448]$} & \multicolumn{3}{|c|}{$[\mathrm{N}=553]$} & \multicolumn{3}{|c|}{$[\mathrm{N}=1.146]$} \\
\hline & Visit 1 & Visit 2 & $\mathrm{p}$ & Visit 1 & Visit 2 & $\mathrm{p}$ & Visit 1 & Visit 2 & $\mathrm{p}$ & Visit 1 & Visit 2 & $\mathrm{p}$ \\
\hline $\begin{array}{c}\text { cough } \\
\text { occurrence } \\
{[\mathrm{N} / \%]}\end{array}$ & $\begin{array}{c}5.162 ; \\
100\end{array}$ & $\begin{array}{c}3.071 \\
59.5\end{array}$ & $<0.001$ & $\begin{array}{c}3.448 \\
100\end{array}$ & $\begin{array}{c}1.786 ; \\
51.8\end{array}$ & 0.001 & $\begin{array}{c}553 \\
100\end{array}$ & $\begin{array}{l}358 \\
64.7\end{array}$ & $<0.001$ & $\begin{array}{c}1.146 ; \\
100\end{array}$ & $\begin{array}{l}919 ; \\
80.2\end{array}$ & $<0.001$ \\
\hline \multicolumn{13}{|c|}{ Cough severity [N;\%] } \\
\hline intense & $\begin{array}{c}3.908 \\
75.7\end{array}$ & $\begin{array}{c}2349 \\
45.5\end{array}$ & $<0.001$ & $\begin{array}{c}2.341 \\
67.9\end{array}$ & $\begin{array}{l}1.340 \\
38.9\end{array}$ & $<0.001$ & $\begin{array}{l}482 ; \\
87.1\end{array}$ & $\begin{array}{l}283 \\
51.2\end{array}$ & $<0.001$ & $\begin{array}{l}1.083 \\
94.5\end{array}$ & $\begin{array}{l}737 \\
64.3\end{array}$ & $<0.001$ \\
\hline $\begin{array}{l}\text { occurence } \\
\text { very often }\end{array}$ & $\begin{array}{c}2.571 ; \\
49.8\end{array}$ & $181 ; 3.5$ & $<0.001$ & $\begin{array}{c}1.403 \\
40.7\end{array}$ & $84 ; 2.4$ & $<0.001$ & $\begin{array}{l}320 \\
57.8\end{array}$ & $29 ; 5.2$ & $<0.001$ & $\begin{array}{l}847 ; \\
73.9\end{array}$ & $77 ; 6.7$ & $<0.001$ \\
\hline $\begin{array}{l}\text { occurence at } \\
\text { night }\end{array}$ & $\begin{array}{c}3.180 \\
61.6\end{array}$ & $111 ; 2.2$ & $<0.001$ & $\begin{array}{c}1.869 \\
54.2\end{array}$ & $57 ; 1.7$ & $<0.001$ & $\begin{array}{l}366 ; \\
66.2\end{array}$ & $13 ; 2.4$ & $<0.001$ & $\begin{array}{l}936 ; \\
81.7\end{array}$ & $44 ; 3.8$ & $<0.001$ \\
\hline $\begin{array}{l}\text { affecting daily } \\
\text { activities }\end{array}$ & $\begin{array}{c}3.237 \\
62.7\end{array}$ & $283 ; 5.5$ & $<0.001$ & $\begin{array}{l}1.855 \\
53.8\end{array}$ & $129 ; 3.7$ & $<0.001$ & $\begin{array}{l}432 ; \\
78.2\end{array}$ & $28 ; 5.1$ & $<0,001$ & $\begin{array}{l}944 ; \\
82.4\end{array}$ & $\begin{array}{l}143 \\
12.5\end{array}$ & $<0.001$ \\
\hline
\end{tabular}


Table 3. Satisfaction of guardians of children with the use of the study syrup

\begin{tabular}{|c|c|c|c|c|c|}
\hline & All study group & $\begin{array}{l}\text { Viral infection of the } \\
\text { upper respiratory } \\
\text { tract }\end{array}$ & $\begin{array}{l}\text { Bacterial infection of } \\
\text { the upper respiratory } \\
\text { tract }\end{array}$ & Bronchitis & $\mathbf{p}$ \\
\hline & {$[\mathrm{N}=5.162]$} & {$[\mathrm{N}=3.448]$} & {$[\mathrm{N}=553]$} & {$[\mathrm{N}=1.146]$} & \\
\hline \multicolumn{6}{|c|}{ Satisfaction from the therapeutic effect after applying the study syrup [N;\%] } \\
\hline very satisfied & $3.520 ; 68.2$ & $2.376 ; 68.9$ & $378 ; 68.4$ & $760 ; 66.3$ & \multirow{4}{*}{0.01} \\
\hline moderately satisfied & $1.399 ; 27.1$ & $927 ; 26.9$ & $157 ; 28.3$ & $310 ; 27.0$ & \\
\hline dissatisfied & $222 ; 4.3$ & $128 ; 3.7$ & $17 ; 3.1$ & $73 ; 6.4$ & \\
\hline very dissatisfied & $21 ; 0.4$ & $17 ; 0.5$ & $1 ; 0.2$ & $3 ; 0.3$ & \\
\hline \multicolumn{6}{|c|}{ Satisfaction with the study syrup dosage method twice a day [N;\%] } \\
\hline very satisfied & $4.104 ; 79.5$ & $2.744 ; 79.6$ & $445 ; 80.5$ & $900 ; 78.5$ & \multirow{4}{*}{ NS } \\
\hline moderately satisfied & $965 ; 18.7$ & $645 ; 18.7$ & $99 ; 17.9$ & $219 ; 19.1$ & \\
\hline dissatisfied & $77 ; 1.5$ & $52 ; 1.5$ & $5 ; 0.9$ & $22 ; 1.9$ & \\
\hline very dissatisfied & $16 ; 0.3$ & $7 ; 0.2$ & $4 ; 0.7$ & $5 ; 0.4$ & \\
\hline \multicolumn{6}{|c|}{ Satisfaction from the small volume of the study syrup to be administered [N;\%] } \\
\hline very satisfied & $4.171 ; 80.8$ & $2.800 ; 81.2$ & $457 ; 82.7$ & $903 ; 78.8$ & \multirow{4}{*}{0.01} \\
\hline moderately satisfied & $919 ; 17.8$ & $600 ; 1.4$ & $90 ; 16.2$ & $222 ; 19.4$ & \\
\hline dissatisfied & $62 ; 1.2$ & $41 ; 1.2$ & $2 ; 0.4$ & $19 ; 1.7$ & \\
\hline very dissatisfied & $10 ; 0.2$ & $7 ; 0.2$ & $4 ; 0.7$ & $2 ; 0.2$ & \\
\hline \multicolumn{6}{|c|}{ Satisfaction with the taste of the study syrup $[\mathrm{N} ; \%]$} \\
\hline very satisfied & $3.247 ; 62.9$ & $2190 ; 63.5$ & $350 ; 63.3$ & $699 ; 61.0$ & \multirow{4}{*}{ NS } \\
\hline moderately satisfied & $1.626 ; 31.5$ & $1069 ; 31.0$ & $174 ; 31.5$ & $376 ; 32.8$ & \\
\hline dissatisfied & $253 ; 4.9$ & $168 ; 4.9$ & $21 ; 3.8$ & $61 ; 5.3$ & \\
\hline very dissatisfied & $36 ; 0.7$ & $21 ; 0.6$ & $8 ; 1.4$ & $10 ; 0.9$ & \\
\hline $\begin{array}{l}\text { Tendency to use the study syrup } \\
\text { for reoccurrence infection with a } \\
\text { productive cough in a child }\end{array}$ & $4.992 ; 96.7$ & $3.348 ; 97.1$ & $545 ; 98.6$ & $1.084 ; 94.6$ & $<0.001$ \\
\hline
\end{tabular}

were also the least likely to use this syrup for subsequent infection with a productive cough in a child $(94.6 \%$ vs. $97.1 \%$ and $98.6 \%, \mathrm{p}<0.001)$ - Table 3.

\section{DISCUSSION}

The presented study is the first Polish, open, multicenter study evaluating the efficacy of ivy leaf dry extract in the treatment of productive cough of different etiologies in children, and the satisfaction of child guardians with the use of study syrup containing this extract.

According to previously published epidemiological data, in which viral infections of the upper respiratory tract in children constituted $70-85 \%$ of all upper respiratory tract infections [9] in the presented study in $66.8 \%$ of observed children the cough was caused by viral infections of the upper respiratory tract. As should be expected, intensive cough was most common in children with bronchitis. In addition, in this subgroup most often the cough occurred at night and very often (several times an hour) and most often affected daily activity.

In accordance with the recommendations, in productive cough facilitate and accelerate the removal of secretions [1] in the observed group in order to enable the removal of secretions accumulated in the respiratory tract, the herbal medicine product containing of ivy leaf dry extract administered twice a day was used, which has expectorant effect, increasing the volume of secretion [2]. The doses of study syrup were adequate to the severity of the cough because in children with viral infections of the upper respiratory tract most often was used $2 \mathrm{ml}$ twice a day and in children with bacterial infections of the upper respiratory tract and bronchitis most often was used $4 \mathrm{ml}$ twice a day. In more than $75 \%$ of the respondents, the control visit took place up to 7 days, which is in line with the recommendation that treatment with preparations containing ivy leaf dry extract should last about 7 days [3].

The use of the product containing of ivy leaf dry extract administered twice a day proved effective because over $40 \%$ of children no longer had a productive cough. In addition, in the all study group and in subgroups with viral and bacterial infections of the upper respiratory tract and bronchitis, the percentage of children with intense cough, cough occurred very often and at night, and affected daily activity significantly decreased. The efficacy of therapy with the preparation containing of ivy leaf dry extract administered twice a day has also been confirmed by the fact that nearly $70 \%$ of guardians of 
children was very satisfied with the resulting therapeutic effect. These results are consistent with the observation that in children aged 2-10 years with acute bronchitis, ivy leaf extract was effective comparable to acetylcysteine (secretolytic drug) [4]. In addition, it has been observed that in adults patients with chronic bronchitis ivy leaf extract could by therapeutically equivalent to ambroxol (secretolytic drug) in improvement of symptoms of cough [9]. Moreover, similar and ever better effectiveness treatment of productive cough ivy leaf extract than ambroxol was described in children aged 7 months -15 years diagnosed with acute inflammatory diseases of the respiratory tract [10]. The efficacy of ivy leaf extract has also been confirmed in other studies in the treatment of productive cough of different etiologies and among patients in different age [5-8]. Also the efficacy of, tested in this study product Hedussin', containing of ivy leaf dry extract, in the treatment of productive cough was positively evaluated during the PAES (post authorization effectiveness study) [11]. In addition, Schmidt et al [12] confirmed efficacy and safety of the 14 days treatment with two galenical formulations of an ivy leaf extract, syrup and cough drops in the group of children aged 0-12 years diagnosed with catarrhal disease of the respiratory tract and/or symptoms of chronic inflammatory recidivating bronchitis.

The results of the present study also showed that the twice daily dosing regimen used to treat cough syrup and the small volume of syrup to be given is important for many guardians because many of them were very satisfied with these the herbal medicine containing of ivy leaf dry extract administered twice a day characteristics. Considering that drug administration in children, especially younger ones, may be met with their protest, the above features may facilitate drug administration. However, based on the results of this study, this hypothesis cannot be confirmed, but it may be an interesting aspect of the next observational study. Although partially is supported by the fact that only slightly more than $60 \%$ of guardians were very satisfied with the taste of this syrup. It should be stressed, that the taste should be assessed by patients who use the drug, so this information is very subjective because the guardians were not asked on what basis they assessed the satisfaction with the taste of the study syrup. It is not known whether this is their own assessment, whether the children asked about it, whether they made observations at the time of administration and drew conclusions from it. It seems that both the efficacy of the study syrup therapy and the dosage method translated into the fact that over $95 \%$ of guardians of the examined children were willing to use the preparation containing of ivy leaf dry extract administered twice a day in the event of a re-occurrence of productive cough. Most often dissatisfied with the therapeutic effect of the study syrup were guardians of children diagnosed with bronchitis. They were also the least likely to use this syrup for the next infection with a productive cough in a child. It seems that this may be due to the fact that in this group during the follow-up visit the cough most often persisted, most often during the follow-up visit it was still intense, occurred frequently and at night and affected the daily functioning of the child. However, this is only a hypothesis because no questions were asked why guardians were dissatisfied with the therapeutic effects of using the study syrup. This part of the results cannot be referred to in the literature, because there are no studies that would assess these aspects in patients using the herbal medicine containing of ivy leaf dry extract administered twice a day.

The strength of the study is the large size of the group and conducting it in many centers throughout Poland. However, the limitation of the study is its questionnaire character and subjective assessment of the severity of cough by guardians.

\section{CONCLUSIONS}

The use of well-established use herbal medicinal product containing of ivy leaf dry extract administered twice a day may be a good alternative to current therapeutic regimens in the treatment of productive cough in children. This recommendation is supported by effectiveness comparable to other medicines and a high level of satisfaction with its use by patients and guardians of children.

\section{REFERENCES}

1. Zasowska-Nowak A, Nowak D. Leki mukoaktywne. Alergoprofil. 2010;6(1):7-13.

2. Lutsenko Yu, Bylka W, Matławska I, Darmohray R. Hedera helix as a medicinal plant. 2010, Vol. 56 No. 1,83-96

3. European Union herbal monograph on Hedera helix L., folium EMA/ HMPC/325716/2017

4. Balbot Yu, Prokhorov E, Mokia S, Yurtseva A. Comparing the efficacy and safety of high-concentrate $(5-7,5 ; 1)$ ivy leaves extract and Acetylcysteine for treatment of children with acute bronchitis. Drugs Ukr. 2004;11:1-4.

5. ESCOP Monographs. European Scientific Cooperative On Phytotherapy. Hederae helices folium. 2nd edn. 2003:241-247.

6. Assessment report on Hedera helix L., folium EMA/HMPC/325715/2017

7. Sieben A, Prenner L, SorkallaT et al. Alpha-hederin, but not hederacoside C and hederagenin from Hedera helix, affects the binding behavior, dynamics and regulation of beta2-adrenergic receptors. Biochemistry. 2009; 48(15):3477-3482.

8. Runkei F, Prenner L, Haberlein H. In-vitro-Studien. Ein Beitrag zum Wirkmechanismus von Efeu. (in Eng.) Pharm Ztg. 2005;4:27-32.

9. Meyer-Wegener J, Liebscher K, Hettich M, Kastner HG. Efeu versus Amboxol bei chronischer Bronchitis. Eine Doppelblindstudie zum Vergleich der klinischen Wirksamkeit und Verträglichkeit von Efeublättertrockenextrakt und Ambroxol. Z Allg Med. 1993;69:61-66.

10. MaidannikV, Duka E, Kachalova O, Efanova A, Svoykina S, Sosnofskaja T. Efficacy of Prospan application in children's diseases of respiratory tract. Pediatrics, Toxicology and Gynecology 2003;4:1-7.

11. Schönknecht K, Fal A.M, Mastalerz-Migas A, Joachimiak M, Doniec Z. Efficacy of dry extract of ivy leaves in the treatment of productive cough, Wiad. Lek. 2017;71(6):1026-1033.

12. Schmidt M, Thomsen M, Schmidt U. Suitability of ivy extract for the treatment of pediatric cough. Phytother. Res. 2012;D0I: 10.1002/ptr.4671. 


\section{ORCID and contributionship}

Magdalena Olszanecka-Glinianowicz-0000-0001-5632-5590 A,C,D,F Zbigniew Doniec - 0000-0003-3896-1053 C,E,F

Karina Schönknecht - 0000-0003-4295-8244 B,E

Agnieszka Almgren-Rachtan ${ }^{B}$

\section{Funding}

PHYTOPHARM KLĘKA SA, POLAND

\section{Conflict of interest}

Magdalena Olszanecka-Glinianowicz - received honorarium for study concept from Europharma

Zbigniew Doniec - received honorarium for co-edition from Europharma

Karina Schönknecht - employed by the funding organization Agnieszka Almgren-Rachtan - received honorarium for co-edition from Europharma

\section{CORRESPONDING AUTHOR}

Magdalena Olszanecka-Glinianowicz

Health Promotion and Obesity Management Unit, Department of Pathophysiology, Medical University of Silesia in Katowice,

Medyków Street 18, 40-752 Katowice, Poland

tel/fax: 322526091

e-mail:magolsza@gmail.com

Received: 24.02 .2020

Accepted: 23.03 .2020

A - Work concept and design, B - Data collection and analysis, C - Responsibility for statistical analysis, D -Writing the article, $\mathbf{E}$-Critical review, $\mathbf{F}$ - Final approval of the article 